\title{
Expression of zinc finger protein ZPR1 mRNA in brain is up-regulated in mice fed a high-fat diet
}

\author{
YOSHIHITO NOGUSA, NORIYUKI YANAKA, NAOKI SUMIYOSHI, KEIKO TAKEDA and NORIHISA KATO
}

Department of Molecular and Applied Bioscience, Graduate School of Biosphere Science, Hiroshima University, 4-4 Kagamiyama 1-chome, Higashi-Hiroshima 739-8528, Japan

Received August 16, 2005; Accepted September 23, 2005

\begin{abstract}
A differential display was performed to analyze differential gene expression in the brain of mice in association with dietary high beef tallow. Consumption of a high beef tallow diet up-regulated the expression of zinc finger protein ZPR1 mRNA in the brain. Expression of ZPR1 mRNA in the cerebellum and hippocampus was elevated in response to the high beef tallow diet. The increased ZPR1 expression in the neuronal, Neuro-2A cells, caused a significant increase in $\mathrm{H}_{2} \mathrm{O}_{2}$-induced cell death. These results suggest that a high beef tallow diet up-regulates ZPR1 mRNA expression in the brain and might increase the vulnerability to oxidative stress.
\end{abstract}

\section{Introduction}

Fats constitute about $40 \%$ of the dietary energy intake in most industrialized Western societies. High intake of animal fat is a risk factor for the development of not only coronary heart disease, diabetes, and cancer $(1,2)$, but also brain diseases including Alzheimer's disease (AD) and Parkinson's disease (PD) (3-7). Morris et al reported that intake of saturated and trans-unsaturated fatty acids was positively associated with the risk of $\mathrm{AD}$, whereas intake of $\omega-6, \omega-3$ polyunsaturated, and monosaturated fatty acids was inversely associated with this risk $(3,4)$. Also, several studies have suggested positive correlations of PD risk with the consumption of total fat, saturated fatty acids, oleic acids, and cholesterol (5-7). In addition, some epidemiological studies have revealed that high intake of total fat, saturated fatty acids, and cholesterol is associated with an increased risk of dementia $(8,9)$.

Correspondence to: Dr Noriyuki Yanaka, Department of Molecular and Applied Bioscience, Graduate School of Biosphere Science, Hiroshima University, 4-4 Kagamiyama 1-chome, Higashi-Hiroshima 739-8528, Japan

E-mail: yanaka@hiroshima-u.ac.jp

Abbreviations: AD, Alzheimer's disease; PD, Parkinson's disease; ZPR1, zinc finger protein ZPR1; EGF, epidermal growth factor; GST, glutathione S-transferase; EF-1 $\alpha$, eukaryotic translation elongation factor $1 \alpha$; SMN, survival motor neuron protein

Key words: high fat diet, brain, ZPR1
Animal studies have demonstrated that cognitive and leaning performance is affected by simple alterations in dietary fatty acid composition. Greenwood et al demonstrated that consumption of a diet high in saturated fatty acids impairs cognitive functions in rats fed diets containing $40 \%$ of energy from various fat blends for three months $(10,11)$. Molteni et al demonstrated that consumption of a diet high in saturated fatty acids for two months impairs leaning performance in rats through down-regulation of several genes, including hippocampal brain-derived neurotrophic factor (BDNF), which is a crucial mediator of neuronal viability and function involved in learning and memory (12). Therefore, elevation of risk for brain disease and cognitive decline induced by a diet high in saturated fatty acids may be mediated by modulation of gene expression in brain. Further searches for dietary fat-responsive genes involving neuronal viability and function are required to elucidate the mechanisms of this increased risk of brain disease and cognitive decline.

The aim of the present study was to identify neuronal genes regulated in response to consumption of a diet containing beef tallow rich in saturated fatty acids using a differential display method. Here, we show that short-term feeding of a high beef tallow diet up-regulated the expression of zinc finger protein ZPR1 (ZPR1) mRNA in brains of mice. ZPR1 is a zinc finger protein that acts as a signaling factor relaying proliferative growth signals from the cell surface to the nucleus $(13,14)$. Our study further demonstrated that higher expression of ZPR1 in the neuronal, Neuro-2A cells, increased $\mathrm{H}_{2} \mathrm{O}_{2}$ induced cell death, suggesting that the higher consumption of a saturated fat diet enhances neuronal vulnerability to oxidative stress through elevation of ZPR1 gene expression.

\section{Materials and methods}

Materials. Purified corn oil and beef tallow were purchased from Nacalai Tesque, Inc. (Kyoto, Japan). Restriction endonucleases and DNA-modifying enzymes were products of Takara Bio (Kyoto, Japan). Dulbecco's modified Eagle's medium (DMEM), fetal calf serum (FCS), and G418 were purchased from Invitrogen. Horseradish peroxidase-conjugated anti-rabbit IgG antibody was purchased from Oncogene.

Animals and diets. Male CD-1 (ICR) mice (6-weeks-old, Charles River, Japan) were housed in groups of three animals 
in a metal cage in a room with controlled temperature $\left(24^{\circ} \mathrm{C}\right)$ and a 12-h light:dark cycle (lights on 08:00-20:00 h). Animals were given free access to diet and deionized water. The mice were maintained according to the Guide for the Care and Use of Laboratory Animals established by Hiroshima University. After being fed a commercial stock diet (MF, Oriental Yeast, Tokyo, Japan) for 1 week, the mice (average $28 \mathrm{~g}$ ) were divided into groups of 9 mice. The composition of the experimental diets is presented in Table I. The feeding experimental period was 28 days.

Differential display. Total RNA was isolated using an RNeasy lipid tissue kit (Qiagen), and differential display was performed as previously described (15). Briefly, $5 \mu \mathrm{g}$ of total RNA was converted to cDNA using a First strand reaction cDNA synthesis kit (Amersham Bioscience). Subsequently, each cDNA was amplified by PCR with 100 different arbitrary primers. After separation by polyacrylamide gel electrophoresis (PAGE), cDNA bands that appeared to be up-regulated in the HB group were recovered and reamplified with the corresponding primer. The cDNAs were sequenced by the dideoxy chain termination method using an Applied Biosystems model 373A automated sequencer and a dye terminator cycle sequencing kit (Amersham Bioscience). The complete cDNA of ZPR1 was cloned by PCR amplification with a mouse brain cDNA library (Clontech) as a template and primers 5'-GAAGCCGCCGCGGGAGCAACGCGTG-3' and 5'-TGCAGTGTGAGTGGCACTGTAGCTG-3'.

Northern blot analysis and in situ hybridization. Total RNA $(10 \mu \mathrm{g})$ was separated by electrophoresis in a $1 \%$ agarose/ 2.2 $\mathrm{M}$ formaldehyde denaturing gel, and were then transferred to a Hybond $\mathrm{N}^{+}$nylon membrane (Amersham Bioscience). ${ }^{32} \mathrm{P}$-labeled cDNA fragments encoding mouse ZPR1 and human $\beta$-actin were used for Northern hybridization as a probe. Hybridization was performed in $6 \mathrm{X}$ sodium saline citrate (SSC), $0.5 \%$ SDS, 5X Denhardt's solution, $100 \mu \mathrm{g} / \mathrm{ml}$ denatured salmon sperm DNA at $65^{\circ} \mathrm{C}$ for $16 \mathrm{~h}$. The membrane was washed with $2 \mathrm{X} \mathrm{SSC} / 0.1 \% \mathrm{SDS}$ at $25^{\circ} \mathrm{C}$, and $0.2 \mathrm{X} \mathrm{SSC} /$ $0.1 \% \mathrm{SDS}$ at $65^{\circ} \mathrm{C}$. The membrane was exposed to a Fuji imaging plate (FUJI photo film, Japan) for an appropriate time. The radioactivity in each band was quantified using an image analyzer and normalized to that of $\beta$-actin mRNA. In situ hybridization was performed using brains of male ICR mice and digoxigenin-labeled probes as described previously (16). Brains of mice were rapidly fixed with paraformaldehyde, and $15-\mu \mathrm{m}$-thick sections were prepared on a cryostat. Digoxigenin-labeled cDNA probes (antisense and sense) were made by in vitro transcription using cDNAs subcloned into pGEM-T vector as templates in the presence of digoxigeninlabeled dUTP (Roche) according to the manufacturer's instructions.

Preparation of recombinant ZPRI protein and anti-ZPRI antibody. The open reading frame of mouse ZPR 1 was subcloned in-frame into the glutathione S-transferase (GST) expression vector pGEX-6P-3 (Amersham Bioscience), generating pGEX-ZPR1. The pGEX-ZPR1 was introduced into the bacterial strain JM109 (Toyobo, Japan). Overexpression of GST-fused ZPR1 protein was performed as
Table I. Composition of experimental diets.

\begin{tabular}{lrrrr}
\hline Ingredients $(\mathrm{g} / \mathrm{kg})$ & LC & LB & HB & UHB \\
\hline Corn oil & 50 & 0 & 0 & 0 \\
Beef tallow & 0 & 50 & 200 & 350 \\
Corn starch & 452 & 452 & 302 & 152 \\
Casein & 200 & 200 & 200 & 200 \\
L-Cystine & 3 & 3 & 3 & 3 \\
Cellulose powder & 50 & 50 & 50 & 50 \\
Vitamin mixture & 10 & 10 & 10 & 10 \\
Salt mixture & 35 & 35 & 35 & 35 \\
Sucrose $^{\mathrm{b}}$ & 200 & 200 & 200 & 200 \\
\hline
\end{tabular}

${ }^{\mathrm{a} A I N-93,},{ }^{\mathrm{b}} \mathrm{AIN}-93 \mathrm{G}$.

described previously (16). The suspended cells were sonicated in an ice-cold solubilization buffer $(50 \mathrm{mM}$ Tris$\mathrm{HCl}, \mathrm{pH} 8.0$, and $1 \mathrm{mM}$ EDTA), and the homogenates were cleared by centrifugation at $15,000 \mathrm{xg}$ for $15 \mathrm{~min}$ at $4^{\circ} \mathrm{C}$. The supernatant was then purified on a column of Glutathione Sepharose 4 Fast Flow (Amersham Bioscience) according to the manufacturer's protocol. Polyclonal antibody raised against ZPR1 was obtained by injecting purified GST-fused ZPR1 into rabbits with Freund's complete adjuvant (DIFCO).

Transfection of ZPRI into Neuro-2A cells and $\mathrm{H}_{2} \mathrm{O}_{2}$-induced cell death in stable transfectants. The open reading frame of ZPR1 was subcloned in-frame into $\mathrm{pEF} / \mathrm{myc} /$ cyto (Invitrogen), adding a C-terminal c-myc tag to ZPR1 (pEF/ZPR1-myc). Neuro-2A cells were cultured in DMEM with $10 \%$ fetal calf serum, 100 units $/ \mathrm{ml}$ penicillin, and $100 \mu \mathrm{g} / \mathrm{ml}$ streptomycin at $37^{\circ} \mathrm{C} / 5 \% \mathrm{CO}_{2}$, and were transfected with the $\mathrm{pEF} / \mathrm{ZPR} 1-$ myc (ZPR-myc) or the empty $\mathrm{pEF} / \mathrm{myc} / \mathrm{cyto}$ vector (mock) using Lipofectamine 2000 (Invitrogen). For establishment of stable transfectants, Neuro-2A cells were treated with $500 \mu \mathrm{g} / \mathrm{ml} \mathrm{G} 418$ for 14 days. G418-resistant colonies were identified and re-seeded in DMEM with $10 \%$ fetal calf serum and $200 \mu \mathrm{g} / \mathrm{ml} \mathrm{G} 418$ at $37^{\circ} \mathrm{C} / 5 \% \mathrm{CO}_{2}$. After the stable transfectants expressing ZPR1-myc protein and mock cells were seeded in 24-well dishes at $2.5 \times 10^{4}$ cells $/ \mathrm{cm}^{2}$, the cells were exposed to $200 \mu \mathrm{M} \mathrm{H}_{2} \mathrm{O}_{2}$ for $6 \mathrm{~h}$. The stable transfectants were washed in PBS and harvested by scraping in $400 \mu 1$ of PBS. After centrifugation for $5 \mathrm{~min}$ at $100 \mathrm{x} \mathrm{g}$, the pellets were resuspended in $100 \mu 1$ of PBS, and subjected to cell counting with a hemocytometer.

Western blot analysis. Neuro-2A cells were washed with icecold PBS, and scraped in an ice-cold RIPA buffer $(10 \mathrm{mM}$ Tris- $\mathrm{HCl}, \mathrm{pH} 7.4,1 \%$ NP-40, $0.1 \%$ sodium deoxycholate, $0.1 \%$ SDS, $0.15 \mathrm{M} \mathrm{NaCl}, 1 \mathrm{mM}$ EDTA). The homogenates were centrifuged at $10,000 \mathrm{x}$ g for $10 \mathrm{~min}$. Protein concentration of the supernatant was determined by the Bio-Rad protein assay kit (Bio-Rad) with BSA as standard. The supernatant (10 $\mu \mathrm{g}$, protein equivalents) was subjected to 
A

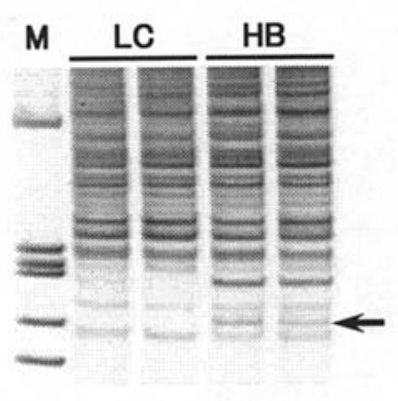

C

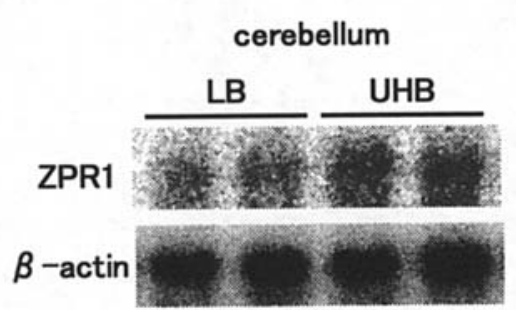

B
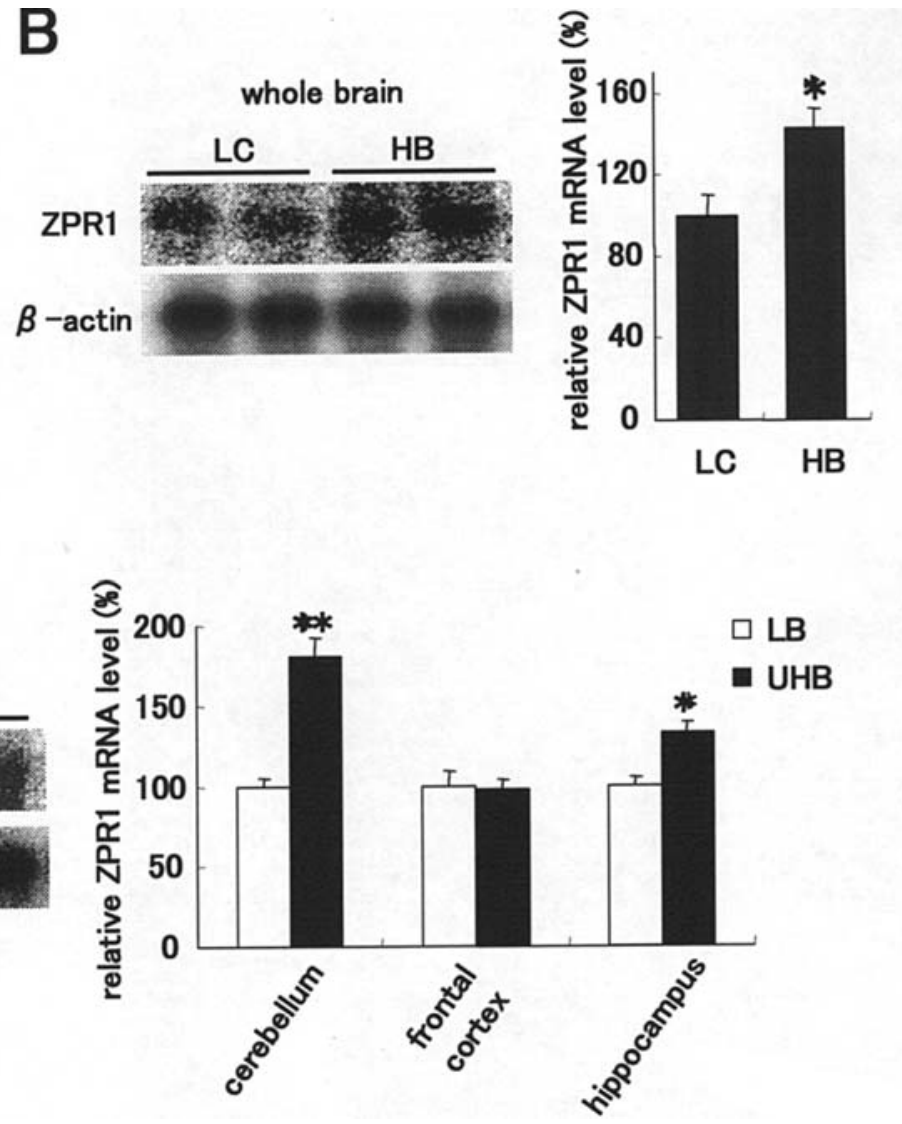

Figure 1. Differential expression of ZPR1 mRNA in mouse brains. A, Differential display PCR of cDNA from brains of mice fed a low corn oil diet (LC) or high beef tallow diet (HB). B, Northern blot analysis for ZPR1 mRNA in the whole brains of mice fed LC or HB. Total RNAs (10 $\mu \mathrm{g})$ were subjected to Northern blot analysis. In the autoradiograms, each lane represents a sample from an individual mouse. The radioactivity in each band was quantified using an image analyzer and normalized to that of $\beta$-actin mRNA. Each value is expressed relative to the mRNA level of the LC group and represents the mean \pm SE ( $\mathrm{n}=3,{ }^{*} \mathrm{P}<0.05$ vs. LC group). C, Northern blot analysis for ZPR1 mRNA in the cerebellum, frontal cortex or hippocampus of mice fed a low beef tallow diet (LB) or ultra high beef tallow diet (UHB). In autoradiograms, each lane represents a sample from the cerebellum of an individual mouse. The radioactivity in each band was quantified using an image analyzer and normalized to that of B-actin mRNA. Each value is expressed relative to the mRNA level of the LB group and represents the mean $\pm \mathrm{SE}\left(\mathrm{n}=3,{ }^{*} \mathrm{P}<0.05,{ }^{* *} \mathrm{P}<0.01\right.$ vs. LB group).

SDS-PAGE and transferred to an Immobilon $\mathrm{P}$ filter (Millipore). The filter was blocked for $18 \mathrm{~h}$ at $4^{\circ} \mathrm{C}$ by soaking in $4 \%$ nonfat dried milk in PBS and was incubated for $18 \mathrm{~h}$ at $4^{\circ} \mathrm{C}$ with anti-ZPR1 anti-body (diluted 1:1000). Signals were detected using horseradish peroxidase-conjugated anti-rabbit $\mathrm{IgG}$ and the enhanced chemiluminescence system (Amersham Bioscience).

Data analysis. In all experiments, means \pm SEM are reported. Statistical comparison for the experiment of cell survival among clones transfected with ZPR1 or empty vector was determined using one-way analysis of variance (one-way ANOVA) and Duncan's multiple-range test (17). Statistical comparison for other experiments was analyzed by Student's t-test.

\section{Results}

Isolation of genes up-regulated in response to a high beef tallow diet. After 4 weeks of the diet, no significant differences were found in body weight, food intake, and the weights of epididymal and perirenal adipose tissues between the LC and HB groups (body weight: LC, $40.9 \pm 1.3 \mathrm{~g}$; HB, $41.1 \pm 1.8 \mathrm{~g}$; food intake: LC, $5.0 \pm 0.8 \mathrm{~g} /$ day; $\mathrm{HB}, 4.3 \pm 0.7 \mathrm{~g} / \mathrm{day}$; adipose tissue weight: LC, $2.02 \pm 0.14 \mathrm{~g}$; HB, $2.06 \pm 0.26 \mathrm{~g}$ ).
To identify genes that were differentially expressed between the LC and HB group, we performed the differential display procedure. The whole brain cDNAs were prepared from two mice in each of these dietary groups, and were subjected to differential display PCR reactions in the presence of different sets of primers with arbitrary sequences. We focused on a cDNA fragment (S6) that was found to be amplified to a greater degree from the whole brain cDNA of the HB group (Fig. 1A). The S6 fragment was reamplified and subcloned into a TA cloning vector. As a result of nucleotide sequencing of the clone, the S6 fragment was identified as a part of mouse zinc finger protein ZPR 1 cDNA. To confirm the differential expression of the ZPR1 gene, total RNA from individual mice of the LC and HB groups was subjected to Northern blot analysis (Fig. 1B). The ZPR1 mRNA level was significantly up-regulated in the HB group compared with the LC group (with a $42 \%$ increase, $\mathrm{P}<0.05$, Fig. 1B).

Beef tallow-responsiveness of expression of ZPRI mRNA in distinct brain regions. In order to analyze the effects of beef tallow intake on ZPR1 mRNA expression in the brain, Northern blot analysis for expression of ZPR1 mRNA was further employed in cerebellum, frontal cortex, and hippocampus from mice fed either LB or UHB. Fig. 1C shows that 


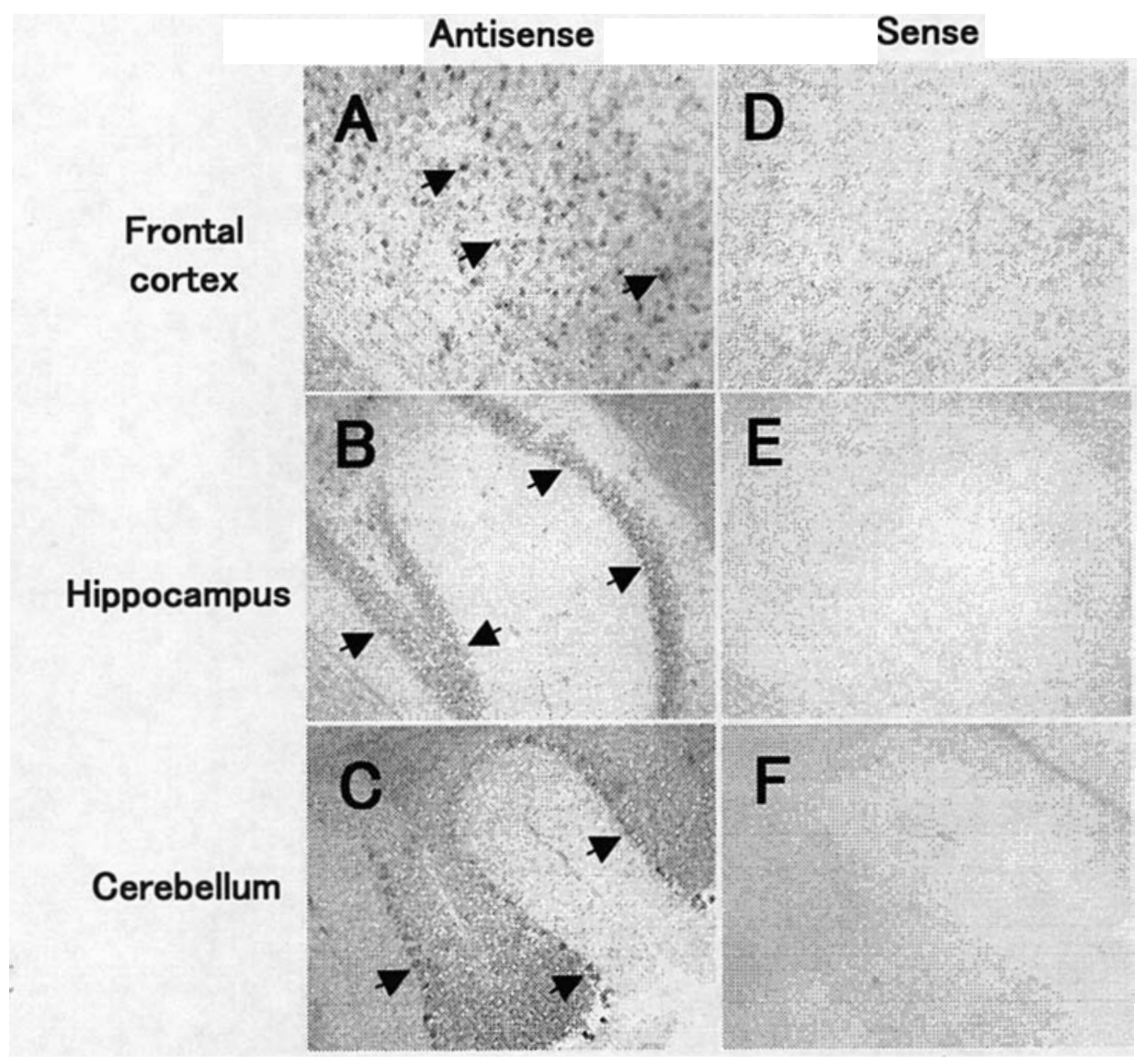

Figure 2. Distribution of ZPR1 mRNA expression in the normal mouse brain. In situ localization of ZPR1 mRNA in mouse brain. Frozen sections of normal mouse brain were hybridized with digoxigenin-labeled antisense or sense cDNA probe complementary to ZPR1 mRNA as described under Materials and methods. For detection of hybridized cDNA probes, anti-digoxigenin antibody conjugated to alkaline phosphatase was used, and color was developed by incubation with 4-nitro blue tetrazolium chloride and X-phosphate solution. Expression of ZPR1 mRNA was observed in the frontal cortex, cerebellum, and hippocampus regions (arrows). In particular, strong signals were detected in most Purkinje cells and in the cornus ammonis and dentate gyrus of the hippocampus

the level of ZPR1 mRNA was significantly up-regulated in the cerebellum (with an $81 \%$ increase, $\mathrm{P}<0.01$ ) and hippocampus (with a $31 \%$ increase, $\mathrm{P}<0.05$ ) regions of the UHB group compared with those of the LB group. No difference of the expression of ZPR1 mRNA was seen in the frontal cortex region.

Expression of ZPRI mRNA in mouse brain. To identify the cell types in which ZPR1 mRNA is expressed, we performed in situ hybridization with ZPR1 cDNA probe and frozen sections from mouse brain. As shown in Fig. 2, ZPR1 mRNA was detected in the frontal cortex (Fig. 2A), cornus ammonis and dentate gyrus of the hippocampus (Fig. 2B), and in Purkinje cells of the cerebellum (Fig. 2C), indicating that neuronal ZPR1 mRNA is mainly expressed in neurons.

Preparation of anti-ZPRI antibody and stable transfectants of Neuro-2A cells that overexpress mouse ZPRI. A polyclonal antibody against a ZPR1 protein was prepared using a bacterially synthesized GST-fused protein. The specificity of the anti-ZPR1 antibody was tested by Western blot analysis of total proteins from COS-7 cells transiently transfected with an expression vector encoding ZPR1-myc. Although no signal was observed in the mock-transfected COS-7 cells, a specific band was detected in the cells transfected with the expression vector encoding ZPR1-myc using anti-ZPR1 antibody (data not shown). The Neuro-2A cells are extensively used as neuronal models in vitro. In addition, the endogenous expression of ZPR1 mRNA was observed in Neuro-2A cells (data not shown). To investigate whether the up-regulation of ZPR1 mRNA expression influences cell survival in the neuronal cell line, we established stably transfected clones of Neuro-2A cells that overexpress mouse ZPR1. As shown in Fig. 3B, elevation of ZPR 1 protein was observed in stably transfected clones, Z3 and Z14, using the anti-ZPR1 polyclonal antibody, but not in mock clones M1 and M2. The expression of ZPR1 mRNA was also up-regulated in the ZPR1-transfected clone Z3 compared with the mock clone M1 (Fig. 3A).

Effect of increased ZPRI expression on $\mathrm{H}_{2} \mathrm{O}_{2}$-induced cell death in Neuro-2A cells. Fig. 3C shows cell survival of the stable transfectants of Neuro-2A exposed to $200 \mu \mathrm{M} \mathrm{H}_{2} \mathrm{O}_{2}$ for $6 \mathrm{~h}$. Exposure to $\mathrm{H}_{2} \mathrm{O}_{2}$ resulted in the reduction of cell survival, with a 72 and a $65 \%$ decrease in the $\mathrm{Z} 3$ and $\mathrm{Z} 14$ clones, respectively, whereas the exposure resulted in only a 48 and a $45 \%$ decrease in the M1 and M2 clones, respectively. There were no significant differences in cell survival of M1, M2, Z3, and $\mathrm{Z} 14$ clones without $\mathrm{H}_{2} \mathrm{O}_{2}$ for $6 \mathrm{~h}$ (data not shown). These 
A

B

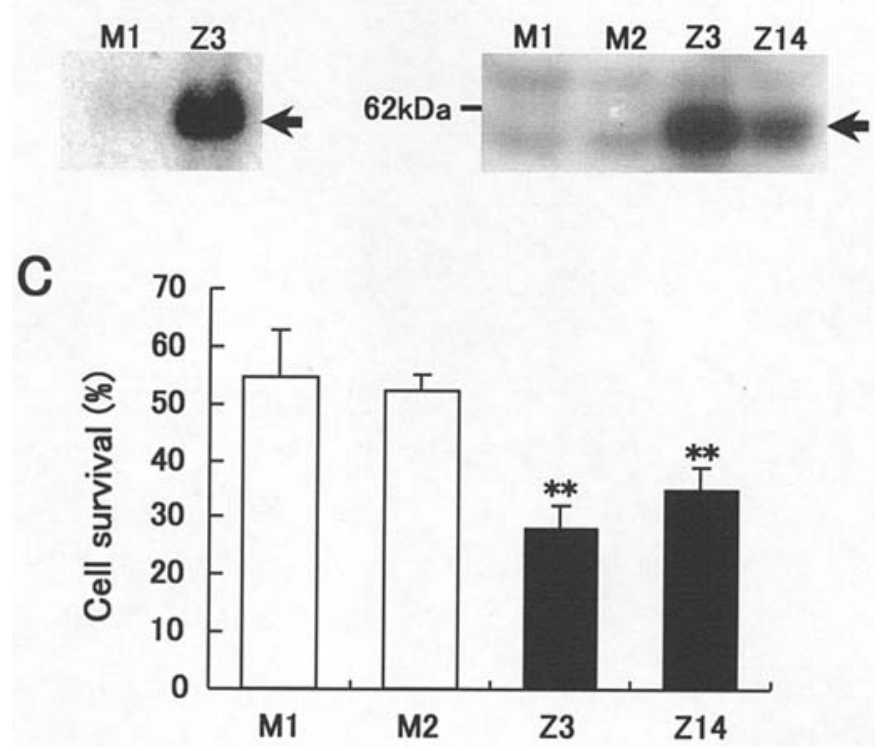

Figure 3. Survival of stable transfectants exposed to $\mathrm{H}_{2} \mathrm{O}_{2}$. A, ZPR1 mRNA was up-regulated in clone ZPR1-3 (Z3) cells compared with clone mock1 (M1) cells. Total RNA $(10 \mu \mathrm{g})$ from Z3 and M1 cells were subjected to Northern blot analysis. B, ZPR1 protein was elevated in clone ZPR1-3 (Z3) and ZPR1-14 (Z14) cells compared with clone mock1 (M1) and mock2 (M2) cells. Whole-cell extracts prepared from Z3, Z14, M1, and M2 cells were subjected to SDS-PAGE, followed by Western blot analysis with antiZPR1 antibody. C, These transfectants were incubated with $200 \mu \mathrm{M} \mathrm{H}_{2} \mathrm{O}_{2}$ for $6 \mathrm{~h}$, followed by measurement of $\mathrm{H}_{2} \mathrm{O}_{2}$-induced cell death. Values are the mean $\pm \mathrm{SE}\left(\mathrm{n}=5,{ }^{* *} \mathrm{P}<0.01\right.$ vs. $\left.\mathrm{M} 1\right)$.

results suggest that up-regulation of ZPR1 expression increases their vulnerability to oxidative stress.

\section{Discussion}

There is increasing evidence that higher consumption of animal fat is involved in the pathogenesis of brain diseases and the impairment of neuronal function. In particular, a higher intake of saturated fatty acids has been shown to elevate the risk of $\mathrm{AD}$ and $\mathrm{PD}$ and to impair cognitive function. However, the molecular mechanisms by which dietary fat influences the brain are poorly understood. In the present study, a differential display method was performed to isolate genes in the mouse brains in response to dietary high beef tallow. Herein it is demonstrated that ZPR1 mRNA expression is up-regulated in the brains of mice fed high beef tallow diets.

$\mathrm{ZPR} 1$ is an essential protein whose amino acid sequence is highly conserved from yeast to mammals (18). ZPR1 has two zinc finger motifs which bind to epidermal growth factor (EGFR) and platelet-derived growth factor receptor (PDGFR) (13). Previous reports have shown that treatment with mitogens induced the release of ZPR1 from the growth factor receptors and translocation to the nucleus (14). Therefore, ZPR1 is supposed to act as a signaling factor relaying proliferative growth signals from the cell-surface to the nucleus. In addition, ZPR1 is shown to bind to eukaryotic polypeptide elongation factor $1 \alpha(\mathrm{EF}-1 \alpha)$ and survival motor neuron protein $(\mathrm{SMN})$ in cytoplasm $(18,19)$. Previous studies demonstrated that the complex with ZPR1, EF-1 $\alpha$ and SMN translocates to the nucleus after stimulation of serum. EF- $1 \alpha$ is known to be involved in the transfer of aminoacyl-tRNA to the ribosome, cytoskeletal organization, apoptosis, and nuclear processes, such as RNA synthesis and mitosis (20). Gangwani et al reported that disruption of the binding of ZPR 1 to EF-1 $\alpha$ results in an accumulation of cells in the G2/M phase of cell cycle and defective growth (18). While, SMN protein implicated in several important physiological pathways, including nucleo-cytoplasmic RNA transportation, uridine-rich small nuclear ribonucleoprotein assembly, RNA transcription, and apoptosis (21-24). Thus, up-regulation of ZPR1 expression might influence the cell cycle, apoptosis and RNA metabolism in neurons.

Neuronal cell death is increasingly recognized as a major contributor to neuropathology such as AD and PD underlying a variety of degenerative diseases of the brain. The cell death of neurons in these disorders is thought to be caused by toxic insults such as abnormal protein aggregates and free-radical generation. The present study demonstrated that up-regulation of ZPR1 expression in Neuro-2A enhanced the $\mathrm{H}_{2} \mathrm{O}_{2}$-induced cell death, suggesting that higher expression of ZPR1 increases the vulnerability to oxidative stress in neurons. Several studies have demonstrated that oxidative stress is a major risk factor for the initiation and progression of sporadic PD and AD $(25,26)$. Because intake of high fat diets, obesity, and diabetes can elevate oxidative stress in plasma and brain $(27,28)$, these observations imply that high animal-fat diet results in cognitive decline and neuronal disorders by elevating oxidative stress in combination with an increase in vulnerability to oxidative stress. Although this study opens important clues to the elucidation of the impact of dietary fat on the development of brain diseases, elucidation of the physiologic function of ZPR1 in neurons will be required for understanding the molecular basis of the effects of high fat diets on the brain functions.

\section{References}

1. Mann JI: Diet and risk of coronary heart disease and type 2 diabetes. Lancet 360: 783-789, 2002.

2. Liu Z, Uesaka T, Watanabe H and Kato N: High fat diet enhances colonic cell proliferation and carcinogenesis in rats by elevating serum leptin. Int J Oncol 19: 1009-1014, 2001.

3. Morris MC, Evans DA, Bienias JL, Tangney CC, Bennett DA, Aggarwal N, Schneider J and Wilson RS: Dietary fats and the risk of incident Alzheimer disease. Arch Neurol 60: 194-200, 2003.

4. Morris MC, Evans DA, Bienias JL, Tangney CC, Bennett DA, Wilson RS, Aggarwal N and Schneider J: Consumption of fish and n-3 fatty acids and risk of incident Alzheimer disease. Arch Neurol 60: 940-946, 2003.

5. Logroscino G, Marder K, Cote L, Tang MX, Shea S and Mayeux R: Dietary lipids and antioxidants in Parkinson's disease: a population-based, case-control study. Ann Neurol 39: 89-94, 1996

6. Johnson CC, Gorell JM, Rybicki BA, Sanders K and Peterson EL: Adult nutrient intake as a risk factor for Parkinson's disease. Int J Epidemiol 28: 1102-1109, 1999.

7. Anderson C, Checkoway H, Franklin GM, Beresford S, Smith-Weller T and Swanson PD: Dietary factors in Parkinson's disease: the role of food groups and specific foods. Mov Disord 14: 21-27, 1999 .

8. Kalmijn S: Fatty acid intake and the risk of dementia and cognitive decline: a review of clinical and epidemiological studies. J Nutr Health Aging 4: 202-207, 2000.

9. Heude B, Ducimetiere P and Berr C: Cognitive decline and fatty acid composition of erythrocyte membranes - the EVA Study. Am J Clin Nutr 77: 803-808, 2003. 
10. Greenwood CE and Winocur G: Learning and memory impairment in rats fed a high saturated fat diet. Behav Neural Biol 53: 74-87, 1990.

11. Greenwood CE and Winocur G: Cognitive impairment in rats fed high-fat diets: a specific effect of saturated fatty-acid intake. Behav Neurosci 110: 451-459, 1996.

12. Molteni R, Barnard RJ, Ying Z, Roberts CK and Gomez-Pinilla F: A high-fat, refined sugar diet reduces hippocampal brainderived neurotrophic factor, neuronal plasticity, and learning. Neuroscience 11: 803-814, 2002.

13. Galcheva-Gargova Z, Konstantinov KN, Wu IH, Klier FG, Barrett T and Davis RJ: Binding of Zinc finger protein ZPR1 to the epidermal growth factor receptor. Science 272: 1797-1802, 1996.

14. Galcheva-Gargova Z, Gangwani L, Konstantinov KN, Mikrut M, Theroux SJ, Enoch T, and Davis RJ: The cytoplasmic zinc finger protein ZPR1 accumulates in the nucleolus of proliferating cells. Mol Biol Cell 9: 2963-2971, 1998.

15. Yanaka N, Imai Y, Kawai E, Akatsuka H, Wakimoto K, Nogusa Y, Kato N, Chiba H, Kotani E, Omori K and Sakurai N: Novel membrane protein containing glycerophosphodiester phosphodiesterase motif is transiently expressed during osteoblast differentiation. J Biol Chem 278: 43595-43602, 2003.

16 Yuasa K, Omori K and Yanaka N: Binding and phosphorylation of a novel germ cell-specific cGMP-dependent protein kinaseanchoring protein by cGMP-dependent protein kinase Ialpha. J Biol Chem 275: 4897-4905, 2000.

17. Duncan DB: Multiple range test for correlated and heteroscedatic means. Biometrics 13: 164-176, 1957.

18. Gangwani L, Mikrut M, Galcheva-Gargova Z and Davis RJ: Interaction of ZPR1 with translation elongation factor-1 $\alpha$ in proliferating cells. J Cell Biol 143: 1471-1484, 1998.
19. Gangwani L, Mikrut M, Theroux S, Sharma M and Davis RJ Spinal muscular atrophy disrupts the interaction of ZPR1 with SMN protein. Nat Cell Biol 3: 376-383, 2001.

20. Ejiri S: Moonlighting functions of polypeptide elongation factor 1 : from actin bundling to zinc finger protein ZPR 1-associated nuclear localization. Biosci Biotech Biochem 66: 1-21, 2002.

21. Schmalbruch H and Haase G: Spinal muscular atrophy: present state. Brain Pathol 11: 231-247, 2001.

22. Paushkin S, Gubitz AK, Massenet S and Dreyfuss G: The SMN complex, an assemblyosome of ribonucleoproteins. Curr Opin Cell Biol 14: 305-312, 2002.

23. Pellizzoni L, Charroux B, Rappsilber J, Mann M and Dreyfuss G: A functional interaction between the survival motor neuron complex and RNA polymerase II. J Cell Biol 152: 75-85, 2001.

24. Gisemann T, Rathke-Hartlieb S, Rothkegel M, Bartsch JW, Buchmeier S, Jockusch BM and Jockusch H: A role for polyproline motifs in the spinal muscular atrophy protein SMN. Profilins bind to and colocalize with smn in nuclear gems. J Biol Chem 274: 37908-37914, 1999.

25. Zhu X, Raina AK, Lee HG, Casadesus G, Smith MA and Perry G: Oxidative stress signalling in Alzheimer's disease. Brain Res 1000: 32-39, 2004.

26. Schapira AH: Disease modification in Parkinson's disease. Lancet Neurol 6: 362-368, 2004

27. Opera EC: Role of oxidative stress in the etiology of type 2 diabetes and the effect of antioxidant supplementation on glycemic control. J Invest Med 108: 175-180, 2004.

28. Beltowski J, Wojcick G, Gorny D and Marciniak A: The effects of dietary-induced obesity on lipid peroxidation, antioxidant enzymes and total plasma antioxidant capacity. J Physiol Pharmacol 51: 883-896, 2000. 